\title{
Civic teacher strategy in the integration of nationalism and tolerance character in school based on pesantren in Yogyakarta city
}

Benaziria Benaziria

Universitas Negeri Yogyakarta, Indonesia

Email: Benaziria0138pasca2016@student.uny.ac.id

Mukhamad Murdiono

Universitas Negeri Yogyakarta, Indonesia

Email:mukhamad_murdiono@uny.ac.id

\begin{abstract}
This research aims to determine the strategy of civic education teachers in integrating nationalist character and tolerance in Junior High School based on pesantren in Yogyakarta City. Research type used in this research is qualitative research with case study method. The research subjects consisted of teachers of civic education who taught at Junior High School based on pesantren in Yogyakarta City. The research data was collected through semi-structured interview, observation and documentation. Data analysis using qualitative analysis techniques, namely data reduction, data presentation and conclusion. Data validity uses two forms of triangulation, ie source triangulation and engineering triangulation. The result of the research is that teachers have integrated nationalist character and tolerance into learning planning and implementation. Learning strategies used to integrate nationalist character and tolerance are lecture method, question and answer, and assignment. Media and learning resources used in the form of books, and video or picture display. This study finds that the implementation of civic education learning done by
\end{abstract}


teachers is not based on lesson planning and effective lecture method is used as a learning strategy if teachers use media and learning resources such as video shows, slide point power usage of the media can increase the enthusiasm of learners.

Keywords: Strategy, Character, Nationalist, Tolerance, Pesantren

\section{Introduction}

The number of news that linked pesantren (Islamic Boarding School) with terrorism acts in mass media, causing streotipe to pesantren, so that appear negative stigma to certain religious group. This negative stigama should not be ignored because it can lead to conflict in multicultural societies. The stigma emerged because of the last few years many mass media homeland preach bombing events and linked the perpetrators of the blast with a particular religion. Attachment of particular religion especially Islam in terrorism problem seen in mentioning background of perpetrator of bombing who ever become santri in a boarding school. Prejudices that tend to negatively affect pesantren lead to negative opinions on pesantren among the community, resulting in a false perception that certain religious groups are intolerant. The seeds of intolerance in Indonesia emerged through educational institutions, one of which is a formal educational institution. The result of SETARA Institute research in 2015 towards high school students in Jakarta and Bandung about their perception of tolerance involving 684 respondents found $11.3 \%$ data of the students supported certain organizations that prohibited the establishment of places of worship, $7.3 \%$ of students approved the use of violence in fighting their beliefs, and $8.1 \%$ agreed to replace Pancasila as the country's foundation, and as many as $4.2 \%$ supported spreading hatred against other religious groups. Of 516 respondents or as many as $75.3 \%$ stated about ISIS, as many as $9.5 \%$ or 49 respondents agreed with this movement. When viewed the total of respondents as much as 684 , then this number 49 indicates as much as $7.2 \%$ or 1 of 14 students agree with ISIS movement.

In review of the social-political dimension that contains the respondents' knowledge about tolerance. This dimension includes the respondent's understanding of tolerance related to religious social life, especially in the school environment and the environment around the respondents, resulting $13.5 \%$ of respondents' data considering the religious background in choosing friends. While the consideration of choosing a leader is also dominant in 
religion background that is as much as $34.5 \%$ of respondents stated that they question the religious background of the leader. Following the Setara Institute research results, in 2016 Puslitjakdikbud, Kemendikbud has conducted surveys at schools in Salatiga, Central Java, and Singkawang, West Kalimantan between July and September 2016. Singkawang and Salatiga were chosen because it represents the multicultural society and is a city with a high level of tolerance. Based on the results of a survey conducted by Puslitjakdikbud, Kemendibud on students, teachers, and headmasters in four high schools, regarding their views on pluralism, diversity and religious tolerance, the results showed that $8.5 \%$ agreed with the idea to change Indonesia became a Shariah country and $7.2 \%$ agreed with the ISIS movement. This agreement does not mean that the students are interested in getting involved in the ISIS movement.

However, this approval number is a serious warning for Indonesia to be wary of the seeds of intolerance. Although the percentage of support for the aspects of the above two research results is small, but the percentage of the support, should be taken seriously from all parties to ensure that the seeds of this tolerance are not spread more extensively. The exclusive nature can be a threat that leads to intolerance in the community. From some of these studies found facts that are not in line with expectations of government and national education goals that have been poured in various policies. The purpose of national education to form citizens of character will be difficult to achieve if schools implement educational processes that ignore nasinonalis values and values of tolerance as the basis of character formation. Schools should suppress the seeds and practices of intolerance, and teachers play an important role in instilling the character of tolerance and fostering national or nationalist awareness among learners. The results that have been described previously expressed a student's views of a thing influenced by the point of view of his teacher. Indirectly teachers play a role to shape the character of the participants and the level of understanding of the values of tolerance is also influenced by the teacher's point of view.

The seeds of intolerance arise due to the narrow understanding of national values. Understanding the value of nationality is important for students because the understanding of the value of nationality raises nationalism awareness or nasinoalism. Nationalism is a citizen's awareness of the local identity of the nation, as well as identity in diversity. Teachers, especially KDP teachers have a strategic role in enhancing nationalist character. Through integration into KDP subjects, the nationalist character directly will foster and develop the character of tolerance to learners. The seeds of intelligence can be eliminated and 
anticipated through the cultivation and development of nationalist character and tolerance to the learners of the cultivation and development of nationalist character and tolerance can not be ignored.

Tolerance and nationalist importance are instilled in order to prevent SARA conflicts that can divide unity and threaten national stability in multicultural countries such as Indonesia. Naumenko and Naumenko (2016: 336) argued that nationalist and tolerant character can prevent and overcome religious extremism, and prevent inter-religious conflict in multicultural countries. Conflict arising from the existence of extremism can be prevented through the internalization of nationalist character and tolerance through education. The learning method used in the educational process can be an instrument for consistent tolerance of consistent karakater formation. The fostering of religious and nationalist tolerance is the first basic step to strengthen interfaith relations. Education is instrumental in shaping learner tolerant and nationalist. Verkuyten and Luuk (2007: 477) mentioned that the tolerance possessed by a person is not influenced by gender, and the level of age, karakater tolerance of a person is strongly influenced by the education that has been taken, the level of education has a positive effect on the growth of the character of tolerance

In formal education the nationalist character and tolerance can be integrated into KDP subjects. Formal education institutions, in this case the school plays an important role to realize the students who are characterized by tolerance and nationalist character. Pesantren as a religion-based formal education institution that has students homogeneous from the religious side, as well as learners who are accustomed to interact with the same religious community in the learning environment has an important role in internalization of the tolerant character. Pesantrens are required to instill a tolerant character to learners, in an effort to realize a harmony life. Pesantren has a strategic role to develop the intellectual life of the nation based on Islamic values, besides pesantren also has a role in realizing ideal life, harmony, peace, maintaining unity, national unity, forming religious citizenship, having a sense of nationality and love of the land.

The integration of nationalist character and tolerance in the learning process at pesantren can be done through civic education subject. PPKn acts as a subject that fosters and instills nationalist character and tolerance to learners, nationalist character and tolerance closely related to civic virtues that encourage the realization of good citizenship. 


\section{Literature Review}

\section{a. Learning strategy}

Learning strategy is one way that can be used to achieve learning objectives. Murdiono (2012: 21) suggests that the learning objectives can be realized, then all components must work together and carry out its functions properly, teachers are not only concerned with or prioritize a single component in organizing learning. Teachers should be able to plan or design the learning process well by involving several learning components that include the selection of methods, materials, media, assessment, and attention to the characterisitk students. Strategies in the context of learning according to Rofa'ah (2016: 67) are the means chosen to deliver instructional materials in a particular teaching environment that includes the nature, scope, and sequence of learning activities that can provide a learning experience to learners. Learning strategy consists of techniques or procedures that will be used to help learners achieve learning goals and all components of teaching materials. Uno, et al (2014: 51) suggests a learning strategy known as learning method which consists of three components, namely learning organizing strategy, learning delivery strategy and learning management strategy.

Learning strategy in educational context according to Hamruni (2012: 1 ) is a plan that contains about a series of activities designed to achieve certain educational goals. In line with this opinion, Sanjaya (2006: 126) also suggests a learning strategy is an action plan or series of activities designed to achieve the learning objectives. Dick and Carey (Hamruni, 2012: 3) suggests non-standalone learning strategies, but consists of two components: learning materials and procedures or stages of learning activities that teachers use in helping learners achieve specific learning goals. Learning strategy is not only limited to the procedures or stages of learning activities, but also on the arrangement of materials or packages of learning programs that will be delivered to learners. Learning strategies can help and facilitate teachers in achieving learning objectives, learning strategies are not only useful for teachers, but also useful for learners, because learning strategies can improve learners' knowledge and make the learning process is not monotonous.

There are several types of learning strategies put forward by some experts. According to Rowntree (Rusman, 2017: 208) in the learning process there are two types of learning strategies that can be used by teachers, namely exposition- 
discovery learning and individual grouping (group strategy and individual learning). The types of learning strategies are classified according to various considerations. The consideration to select the learning strategy produces the types of learning that include: 1) Consideration of message processing process consisting of deductive learning strategy which emphasizes on verbal material delivery process and inductive learning strategy. 2) Considerations of message messaging, consisting of expository learning strategies and heuristic learning strategies. 3) Consideration of teacher and student interaction, consist of faceto-face learning strategy and learning strategy through media. 4) The taxonomic considerations of learning outcomes consist of cognitive teaching and learning strategies, skills teaching and learning strategies and affective learning strategies. 5) Teacher setting considerations, including a teacher's learning strategy and team learning strategy.

6) Based on the consideration of the number of learners, which consists of classical learning strategies, small group learning strategies and individual learning strategies. Some types of learning strategies can be selected by the teacher based on the need to achieve the learning objectives. The teacher chooses the learning strategy used should consider several aspects. Aspects to determine learning strategies need to be considered in order to achieve the learning objectives.

\section{b. Citizenship education or Civic education}

Citizenship education or Civics is a subject designed to prepare young people to play an active role in society (Cogan (1999:4) Civics or the curriculum of 2013 called Civics, in some countries have different terms. There are countries that implement Civics with integrate into social studies, as cross curricular is incorporated into the whole curriculum order into all subjects, while in Indonesia PPKn is the subject of self-subject (saparate). The learning of citizenship education in the education curriculum of Indonesia is applied to all levels of education, from basic education to university education as contained in RI Law no. 20 of 2003 on the Education Article 37 Paragraph (1) letter $b$ stating that the curriculum of elementary and secondary education shall contain civic education. Similarly, in paragraph (2) letter b stated that the curriculum of higher education must contain civic education (Kemenristekdikti, 2016). Currently Civics in the curriculum applicable in education in Indonesia, ie the 2013 curriculum uses the term PPKn. The teacher in carrying out his 
profession must have four competencies, namely pedagogic, personality, social and professional competence (Law No. 14 of 2005, Permendikans no 16 2007). Civic education teachers are teachers who take on civic education subjects. Winanrno (2013: 63) suggests that civic education teachers should have four such competencies. The pedagogic competence that PPKn teachers must possess is that the PPKn teachers should be familiar with the various learning theories and principles of civic education learning, the civic education teachers should have knowledge and skills about the approaches, models, strategies, media and instructional techniques that educate in KDP subject, PPKn must understand well the purpose of KDP learning, civic education teachers should understand the principles of assessment, evaluation and learning outcomes of civid education, and civic education teachers should have knowledge and skills in civic educationreseacrh action class. Civic education teachers are also required to have professional competence. The professional competence of civic education teachers is the ability of civic education teachers to master the materials, structures, concepts, and scientific mindsets that support civic education, understanding the substance of civic education that includes civic knowledge, values, and citizenship, as well as citizenship skills.

\section{c. Nationalist Character and Tolerance}

\section{1) Nationalist Character}

Nationalism relates to a nation or nation. Anderson (2002: 8) suggests a nation or a nation is a political community and is conceived as something that is inherently limited as well as sovereign. The nation is something "imagined" because even the smallest members of the nation will not know and do not know most of the other members, will not face to face with them, may not even hear about them. Everyone who belongs to a nation lives on a shadow of their togetherness. Nationalism is the product of collective imagination built through appreciation (Smith, 2003: 1) Storddard (Hamidi, 2010: 167-168) suggests nationalism is a spiritual state, or a belief shared by and possessed by some people about the sense of nationality to become a nation together. Unlike Strodddart, Heuken suggests nationalism has two meanings, first nationalism is an outrageous, narrow, and arrogant attitude. The nationalist attitude shows no respect for others properly. What benefits the nation itself is right, even if it tramples the rights and interests of other nations. Therefore, nationalism divorces the nation-one with another nation is not the attitude that unites the 
nation. Such an attitude is classified as narrow or fanatical and overwhelming nationalism. In contrast to the negative nationalism that Heuken expressed, Hamidi (2010: 168) posited positive nationalism that is the attitude that fights and defends the independence, as well as the nation's self-esteem while respecting other nations. This attitude shows the attitude of making difference as a means of unifying differences that include differences in race, race, nation, religion. The positive attitude of nationalism serves to foster a sense of identity, togetherness in the state and to fill the independence that has been obtained.

Smith (2003: 236) states that nationalism is a political doctrine with a set of core ideas that the world is divided into several countries and loyalty to the nation and state is a must. Nationalism in the education system serves to instill strong loyalty to its citizens and maintain the high culture needed in modern society. The public education system reflects and expresses the national value system of a country. In Indonesia the nationalist character is two of the five characters that must be implanted contained in the national character education movement of the nation which is also an integral part of the nation character revolution and revolution of mental movement in the educational environment that aims to encourage all stakeholders to make changes paradigm, thought and how to act, in managing the school. There are five main values of character that become the main focus in the national movement of character education and mental revolution movement that is: religious, nationalist, independent, mutual cooperation and integrity.

\section{2) Tolerance Character}

Tolerance is one of the principles of democracy that helps society in living life in multicultural society. Jackson (Raihani, 2011:

26) tolerance relates to patience. Tolerance includes values of respect and recognition. Rapp and Freitag (2015: 1033) suggests tolerance to be understood as a positive belief in the absence of prejudice, racism or ethnocentrism. In this sense, UNESCO expressed tolerance as a positive recognition of human rights and civil liberties. Grawemeyer (Tokkulinova, 2015: 170) describes tolerance as respect, acceptance and appreciation of diversity, form of expression and the way we become human. Tolerance grows because it is nurtured by knowledge, openness, communication and freedom of thought, conscience and trust. Tolerance is a harmony in diversity. Borgida et al (2011: 324-332) states that tolerance is an act of restraint not to interfere in the affairs of others, even if 
such actions are not favored. Thus, tolerance can be understood as an act of survival or persistence with something that is not approved.

Tolerance in modern society has a very important function. Tolerance acts as a value orientation and as a rule of social action, and as a political necessity. According to Aubakirova et al (2016: 5035) tolerance is manifested in various areas of community life (moral, legal, political, religious, economic, etc.), which serves as an important prerequisite for cultural interaction. The lack of tolerance in the community can worsen the social situation of the community itself. Low tolerance or intolerant attitude can lead to social conflict in society.

Hutchison (2014: 797) also expressed intolerant behavior not only as a trigger for the onset of conflict, but also post-conflict intolerant attitudes that could hamper reconciliation, the realization of peace. Van Waarden (Tillson, 2017: 1) integrating tolerance in the education sphere serves to foster mutual respect among citizens, promotes knowledge and respect for the citizens' constitutional rights, develops democratic participatory skills, provides a basic understanding of others. Tolerance works to create peace. A tolerant attitude aims at creating a society that lives side by side in a peaceful diversity frame. Tolerance can be developed or integrated through Civics learning. Civics can be promoted in developing spiritual and social attitudes of citizens. Develop spiritual attitudes and social attitudes aimed at fostering behavior in order to characterize learners' character. One of the characters developed through the Civics subject is the character of tolerance. The character of tolerance in the Civics subject falls into the category of spitual attitudes. The indicators of tolerance in PPKn include: 1) actions that value differences in worship. 2) respecting friends of different religions, 3) making friends without differentiating religion, 4) not disturbing friends who are in the worship, 5) respecting other religious holidays, 6) not speaking ill of other religions (Kemendikbud, 2017: 5).

Smeekes (2012: 1412) expresses tolerance as a space for receiving cultural and religious diversity, and preventing inter- religious conflict. the concept of tolerance continues to evolve, the development of immigration gave birth to new ideas about the concept of tolerance that serves to deal with diversity or multicultural. Indonesia as a multicultural country has over 220 million inhabitants, and is a country with heterogeneous populations of various ethnicities and religions. Indonesia is not a secular country nor a religious state. The ideology embraced by Indonesia is the Ideology of Pancasila. As a multicultural nation, internalization of tolerance to citizens is important in anticipation of the emergence of social conflict. Therefore educational 
institutions should foster and continue to foster the character of tolerance in learners as young citizens. Bennett (2001: 138) argued that society must have a correct understanding of tolerance of the importance of tolerance. Tolerance is an attitude that treats people with respect and without hatred. Indonesians are vulnerable to social conflicts caused by ethnic, religious, racial, and intergroup relations. The development of tolerance in multicultural society in Indonesia is framed by the slogan of Bhinneka Tunggal Ika. Bhinneka Tunggal Ika from an "ideological concept" was developed for the purpose of the state to be a "pedagogical concept" for civic education.

\section{d. Pesantren (Islamic Boarding School)}

Indonesian society is a plural society, as well as Islamic organizations, this is reflected in the many Islamic organizations such as Muhammadiyah, NU, HTI, FPI, LDII, JIL, Salaf groups, and so forth. Some of these understandings have different understandings, there is a modern and also understood fundamentalist. The number of Islamic organizations in Indonesia, as well as the advancement of technology and the rapid flow of globalization, is a challenge and a very complex issue that must be faced and answered by pesantren. Marwazi (2012: 39), Pesantren (pesantren) is an educational institution based on Indonesian culture which is a continuation of previous religious culture that experienced the Islamization process, pesantren education system is loaded with character education and contains education of state love and even state defense. The cultivation of patriotic values of the nation can be done through the pesantren education system, integratively, there has been material love of the country and defend the state in the pesantren education system, although not refuse to teach Civics. Thus, the curriculum of the pesantren is richer in the value of love for the fatherland and the stat

Pesantren is the oldest religious education institution in Indonesia. Zamroni (2005: 178-179) argued pesantren is an educational institution organized with the aim of teaching the basics of Islam. Pesantren education prioritizes the independence of an individual. Education in pesantren is often also recognized by education that teaches, and broadcasts the basics of Islam to santri and society. Abdurahman (2016: 289) suggests pesantren or other terms Boarding School is a place where Islamic students and teachers (Kiai) or their representatives learn formally, informally and informally whether in the morning, during the day, or at night. Pesantren aims to educate learners, create 
qualified scholars and religious leaders. According to Abdurahman (2016: 289) teaching methods apply effective methods, pesantren not only develop the cognitive domain only, but also focus on personal guidance by kiai (teacher) and qualitative understanding of learners not only the cognitive aspects through lectures, but also prioritize the moral aspect and spiritual learners. In addition, it also trains and enhances the affective sphere of learners to value spiritual values and humanity, instilling good behavior such as honesty, morality and preparing them to recognize religious ethics and putting religious values on top of other values.

The results of Tan (2014: 50) stated that there are three types of Islamic schools in Indonesia, namely pesantren, madrasah, and Islamic school, from the three types of Islamic schools, pesantren is the oldest and is considered as a bulwark of Islamic knowledge as well a leading provider of Islamic scholars and teachers. Burhanudin and Jamhari (Tan, 2014: 50) classified pesantren into three types, namely: 1) The traditional Pesantren type is a pesantren that focuses on traditional Islam and is likely to be affiliated with Nahdlatul Ulama (NU). NU, is an association of Muslim scholars who usually have their own pesantren and teach classical Islamic texts to learners. Traditional pesantrens are distinguished from the usual practice of worship and "mystic". An example is a visit to the great Kiai's grave to gain grace and blessings (holiness, virtue as an inherent spiritual force). Other practices include religious songs (dhikr, literally meaning remembrance of Allah) and certain worship given by kiai to their followers. 2) Modern pesantren type, modernization of pesantren education by introducing structured systems such as owning, classrooms, textbooks and reforming ethos. Most modern pesantren are affiliated with Muhammadiyah's mass-based Muslim associations such as NU. But unlike NU, it is "reformist" in the sense that it rejects mystical beliefs and piety and practices endorsed by $\mathrm{NU}$ and that is found in traditional pesantren. Muhammadiyah views these beliefs and practices as syncretic and Islamic. 3) The type of independent (independent) pesantren not related to NU or Muhammadiyah, and tends to adopt Salafi ideological beliefs. In this study, the object of research focused on junior high schools based on boarding schools. The pesantren-based junior high school is one that implements Islamic values and knowledge.

In this research, the object of research is pesantren-based schools. Nurochim (2016:

73) suggests pesantren-based schools or SBP is one model of Islamic education which is a combination of two social systems, namely the social 
system of pesantren and school social system. In line with that opinion, Suhardi (2010: 321)) also pointed out that pesantren is a traditional Islamic educational institution that understands, deepens, and practices religious teachings by emphasizing the importance of religious morality as a guideline of everyday behavior. While pesantren-based schools (SBP) is an educational institution that combines formal schooling, especially junior high school, with boarding school aims to produce a more powerful and complete education system. The development of a model of pesantren-based junior high school education is an effort to integrate the excellence of the implementation of the education system in schools and the excellence of the implementation of the education system in boarding schools.

The model of pesantren-based school education (SBP) aims to create human resources as well as scientists as a whole, so that it can play a role in social system. The establishment of Pesantren-Based School (SBP) comes from the discussions of the Ministry of Religious Affairs, Ministry of National Education, and Center for Educational Development (CERDEV) UIN Syarif Hidayatullah Jakarta. Pesantren-Based School (SBP) is an educational model that is capable of developing multiple intelligence, spiritual-religious, life skills, and strengthening of national character. Pesantren-Based Schooling (SBP) is a school model that integrates the benefits of education systems held in schools and the excellence of the education system in pesantren (Nurochim, 2016: 81). SBP is a pre- eminent education model that integrates the implementation of a school system that focuses on developing the skills of science and skills, as well as the development of religious attitudes and practices, the enhancement of morality and independence in life.

\section{Methods}

This research was conducted at SMP based pesantren in Yogyakarta City, covering MTs Negeri, MTs Swasta and SMP Islam Terpadu Se-Kota Yogyakarta. The informant in this research is the Civics Teacher in the junior high school based pesantren boarding school of Yogyakarta city. This research uses purposive technique in determining resource. According to Creswell (2015: 217) a purposive technique is a technique by which the researcher selects and decides the individuals and places to be examined as they can specifically provide an understanding of the problems and phenomena related to the research. Determination of resource in the research consider several criteria. The criteria 
that the researcher determines in the research resource are: 1) The party who knows how to integrate the character of tolerance and nationalist through the learning of Civics, 2) the parties who know the obstacles in integrating the character of tolerance and nationalist, 3) the parties who know the solution in overcoming the obstacles- obstacles in integrating the character of tolerance and nationalist, and 4) teachers who have experience of teaching over five years. Based on these criteria, then the subject of research in this study is the Civics teacher at SMP-based pesantren all over Yogyakarta. Data collection techniques in this study using observation techniques, interviews and documentation. The validity of the data in this study includes the test credibility (validity of interbal) trasnferabillity (external validity) dependability (relaibilitas) and confirmability (objectivity). In this research the validity of data is done by Test of Credibility. The credibility test in this research is done by using two triangulation techniques, ie triangulation of source and triangulation technique

Data analysis used in this study using qualitative data analysis, done at the time of data took place and after data collection is completed in certain period. Data analysis in this research is done on interview data, observation data and data result of document analysis, if data obtained from result of analysis feels unsatisfactory, hence researcher will question again until certain stages, so that obtained credible data.

Data analysis used in this research using Miles and Huberman data analysis model (1992: 20) include reduction, data presentation and conclusion. Data analysis is done interactively and continuously until complete, until the data saturated, meaning there is no longer additional data acquisition meaning.

\section{Results and Discussions}

Learning objectives can be achieved optimally if teachers have and implement learning strategies while implementing the learning process. Before the implementation of learning, teachers first create a learning plan that describes the implementation of learning activities that teachers will do from the beginning of learning to the end of learning. Preparation and planning of the aims for the implementation of learning to run effectively resulting in optimal learning outcomes, whether the results of cognitive learning, skills and effective or attitudes. During the interview about what preparation I prepared the teacher before teaching the Civics in the class some of the resource persons suggested before teaching in the class the speakers prepared the instructional 
administration, such as student attendance, student progress book, print book and Civic learning plan. When researchers observe the preparation of the teacher before teaching. The result of the observation indicate that at the time of entering the class, the teacher only brought the students' attendance, the progress book of the students and the book of Civ as the source and the learning media, and the next observation the researcher obtained the data besides bringing the student's attendance, the progress book of the learner and the $\mathrm{Cn}$ print book, laptops and power point display, images / video that are served via LCD and projector as media and learning resources. The results of observation showed that the speakers did not prepare and bring the planing laerning civic education while carrying out teaching and learning activities in the classroom. Teachers carry only Civic print books, student attendance, progress books learners, and some that bring learning media such as print books Civic education, power point, laptop, and video impressions.

Based on the interviews all the speakers realized the values of tolerance and nationalism are very important taught and implanted to the learners. The integration of nationalist character and tolerance into Civic learning is tailored to the context of each school. The speakers have understood the role of civic education as a subject that aims to shape, cultivate and develop the characteristics of learners, including nationalist character and tolerance. Nationalist values and tolerance imparted to learners should be based on Islamic values and concepts of tolerance that are taught and developed should not be deviated from the Islamic creed. Based on interviews with these speakers, the nationalist values and the tolerance implanted should not be deviated from the Islamic creed. The results of interviews on nationalist concepts of tolerance and why these two characters need to be integrated into the Civics subjects are directly proportional to the results of documentation in the form of an analysis of the lesson plans held by the resource persons, as well as the observation results when the implementation of learning in the classroom.

The result of the observation shows the nationalist attitude which the source of cultivation and example to the learners is the attitude that learn earnestly, and keep achievement, not fighting, protecting environment, discipline, and loving culture itself is one of the examples of nationalist instilled and exemplified to the students. The nationalist character integrated in the learning plan and the nationalist values that the resource persons teach, develop and plant to the students in the pesantren-based junior high school in Yogyakarta city in accordance with the nationalist values prioritized by 
Kemendibud that there are five main values of character that become the focus (religious tolerance, peace of mind, friendship, not imposing will, respect for differences in religion and beliefs, anti-harassment and violence, friendship, inter-faith cooperation and trust, sincerity and self-confidence), nationalist, (obeying the law, discipline, love the homeland, protect the environment, sacrifice, appreciation of the nation's own culture, keep the cultural culture of the nation's own culture, excel in achievement). independent, mutual cooperation and integrity. The five values of the character can be applied in school either contextually or universally (Kemendibud, 2016: 9)

Implementation of the integration of nationalist character and tolerance in the learning of Civics done with the lecture method interspersed with question and answer between the speakers and learners. teachers also use printed books as media and learning resources Civics. The observation result shows that there are some speakers who use media and additional learning resources such as slide power point, video display, and handout. The steps of the lecture method used by the speakers, which explains the material with the media and learning resources in the form of $\mathrm{Cd}$ print books, and sometimes using images and vidoe $\mathrm{d}$ through LCD and Projector, teacher to provide examples of material explicitly related to environmental context learners, then held questions and answers between teachers and learners. Learning strategy using this lecture method is purposely select teacher because according to the teacher, this lecture method matches with the character of their learners. Judging from the type, the teaching strategy of the lecture that was chosen and used by the teachers of SMP-based pesantren in Yogyakarta City is a direct learning strategy or in terms used by Majid (2013: 11) called direct instruction, which is teacher-centered learning strategy, in the form of lecture methods, didactic questions, explicit teaching, practice and practice, and demonstrations.

There are some barriers experienced by Civics teachers in integrating nationalist character and tolerance, both in planning, implementation and assessment. The result of the observation about the obstacles experienced by the teacher during the implementation of learning in class, namely the teacher difficulties in carrying out the learning of Civics in accordance with the lesson plans that have been prepared. Almost the average teacher does not use the Learning Plan while implementing the Civic learning process. Another obstacle experienced by Civics teachers in integrating nationalist character and tolerance during the implementation of learning is the placement or compilation of Civic learning hours placed in the last hour of the lesson, so that the motivation to 
learn the students tend to decline. the resource participants activities outside the hours of very solid. Because schools are boarding school schools and apply full day school. follow the learning in the classroom learners should learning activities during the Dormitory. Barriers experienced by Civics teachers in integrating nationalist character and tolerance are overcome by teachers with several attempts. To overcome difficulties in creating and preparing RPP Civics. The teachers utilize the subject matter teachers (MGMP) PKn As a forum to exchange ideas and make the RPP together. Based on the triangulation table of resource persons utilize MGMP Civics as a forum to create a lesson plan (RPP) together. The efforts that the resource persons do this create new problems, ie the lesson plans that have been made are not in accordance with the characteristics of learners in each school, so that when the implementation of learning the speakers did not perform the learning steps in accordance with the lesson plan.

The implementation of Civics learning in integrating nationalist character and tolerance is not maximally done, because based on the interview data and the observation result of the speakers revealed that the RPP they use is flexible and in the implementation of the teacher's learning does not bring the lesson plan, the lesson uses the lectures, assignments, and question and answer between students and teachers, question and answer was more silent than active. Implementation of learning that teachers do not through careful planning. The results of interviews about the efforts that teachers do to overcome obstacles in the implementation of learning Civics that contains the character of tolerance and nationalist not in accordance with the RPP, resulting in data on average teachers implementing learning that is flexible. While obstacles in the form of facilities and infrastructure do not experience obstacles and difficulties in terms of availability of books. Based on observation results of SMP IT researchers, Masjid Syuhada has good book availability, even every class is LCD which can be used as media and learning resource. The same thing is also found in MTs Muhammadiyah Mualimmat and MTs Muhammadiyah Muallimin each available LCD classroom. Slightly different from MTs Nurul Ummah even though in every class have not yet LCD, but school provide LCD which can be brought and used in class.

In addition to efforts to overcome obstacles in the implementation of learning. Teachers also make efforts to overcome obstacles in the implementation of the assessment. To overcome the barriers of attitude assessment that arise due to the large number of learners. Based on triangulation tables the speakers chose to use observation sheets instead of using self-assessment and inter-friend 
appraisal. The observation sheets used by the sources contain daily notes on the development of learners' attitudes or are called the attitude development journal. Attitudinal attitudes were not only done during the course of my classroom, but the triangulation table indicated that the resource person also conducted an attitude assessment outside the teaching and learning activities. The attitudinal development journal (attached) also includes indicators of attitude assessment divided into four indicators, namely very good, good, good enough, and not good. The final result of the student attitude attestation is in the form of a letter, ie A describes very well, $\mathrm{B}=\operatorname{good}, \mathrm{C}=\operatorname{good}$ enough and $\mathrm{D}$ $=$ not good.

The triangulation table indicates that the speakers have a persuasive approach to the students whose attitudes are categorized as unfavorable or unfavorable. The next data shows that the resource persons are also working with Religious teachers and BK teachers to foster the characters of the students who are categorized less well. Results of data showing teachers using only observation sheets in the form of attitude development journals do not conflict with the national education curriculum in 2013. Kemedibud (2017: 12) contains an assessment of attitudes consisting of the main assessment and assessment of support. The main assessment is done through daily observations written in the daily journal. While supporting assessment is obtained from self-assessment and assessment of friends, the results can be used as a confirmation of the results of attitude assessment by educators. Attitude assessment techniques using observation sheets, or through interviews, anecdotal records, and incidental records are the main assessments.

The concept of tolerance that is integrated in learning Civics in juniorbased SMP pesantren as Yogyakarta is a concept of tolerance in accordance with the context of Islam, should not ridicule of Islamic religious values. The concepts and values of tolerance imparted to the learners at the pesantrenbased junior high school use a pedagogical approach. The values of tolerance that should not be contradictory or deviate from religious aims are in line with those proposed by Djupe and Calfano (2011: 769) Religious attributes have an important correlation to the formation of tolerance towards disadvantaged and least favored groups. religious beliefs or dogmas lead to the emergence of intolerant attitudes because religious people are unlikely to accept lifestyles or life behaviors that are contrary to the teachings of the books they believe. Based on the above opinion, the religion is believed and adhered to be the basis of a person in understanding the concept of tolerance. Religion also affects the 
attitude of tolerance possessed by indirectly or indirectly directs and guides or guides people about the concept of tolerance.

A pedagogical approach by teacher to integrate nationalist character and tolerance in the form of a direct instruction approach, where teachers choose and use instructional strategies in the form of lecturing methods that are in between questions in the form of question and answer between learners and teachers, and end with the assignment, and make printed book a media and learning resource. This is in contrast to the opinions expressed by Murdiono (2010: 20) which suggests the right type of strategy used by Civics teachers to achieve the goals of Civics is a dialogue-critical, hands-on, collaborative and cooperative learning strategy.

This study also produced some findings. These findings come from observations, documentation and interviews. These findings are in the form of making learning tools such as prosem, prota, syllabus, learning plan, etc. only used as documentation for the purpose of school accreditation, and for certification, and used for supervision. In the implementation of teaching and learning activities in the classroom teachers do not carry and use lesson plans. Pursuit devices, especially lesson plans do not fit into one of the goals of Civics, ie, to form ecological citizens or ecological citizenship. Learning devices are made only waste paper, while the implementation of teacher learning is not guided by the lesson plan.

Effective lecture method is used as a learning strategy if teachers use media and learning resources such as video shows, slide point power usage of the media can increase the enthusiasm of learners. The lecture method is also very effective to use if the teacher has a great voice and is good at playing the appropriate word splits and intonation. The next finding is that there are unscrupulous teachers who still consider nationalists to be contrary to Islamic values.

\section{Conclusion}

Based on the results of research and discussion that has been done, it can be concluded that the Civics teacher at SMP- based pesantren in Yogyakarta City has integrated the nationalist character and tolerance into the content of the Civics learning plan. Both of these characters are listed in the RPP in conformity with the material or basic competence of Civics. Learning strategy used by junior high school based on pesantren in Yogyakarta City to integrate 
nationalist character and tolerance to learners using lecture method interspersed with question and answer between learners and teachers, then assigned in the form of questions. The sources and instructional media used include the PPKn printed books. Civics teachers SMP-based pesantren as a city of Yogyakarta did not implement the learning approach as has been summarized in the RPP Civics. The implementation of Civics learning is not guided by RPP. Rpp is only used as a document for accreditation purposes, and is only used during supervision. Teaching teachers are guided by core competencies- Civic basic competencies.

Internalization of nationalist character to learners has been in accordance with nationalist character indicator that has been established by the Ministry of National Education, namely love of the homeland, discipline, preserving the environment, respecting diversity. While the internalization of tolerance character adjusted to the values of Islam, namely the concept and attitude of tolerance that should not deviate from the Islamic creed. Assesment nationalist character and tolerance using the guidance of observation in the form of a journal of the development of the attitude of learners that contains notes learners behavior. Assessment of attitudes done by the teacher while in the classroom and outside the classroom.

\section{Suggestions}

After conducting research on the strategy of Civics teacher in integrating nationalist character and tolerance at junior high school based on pesantren in Yogyakarta city, the researcher proposed some suggestions:

a. For the Education Office and schools

1) Need to provide workshops in the form of training or courses using technology, especially laptop, LCD, and the use of projectors as media and learning resources to teachers, especially teachers aged 45 years and over. The education office also needs to revise learning tools, especially RPP in a simpler form.

2) Education and school offices need to provide regular public speaking training to teachers.

3) Universities, especially LPTKs include communication science as one of the subjects for prospective teachers to have a basic provision of how to communicate that the material presented by the teacher can be well understood by the students. 
b. For teachers

1) Teachers should evaluate the material already learned in the classroom

2) Teachers should approach the teaching methods that are more appropriate to the characteristics of learners.

3) Teachers should not be anticritic and closed to evaluations provided by learners Teachers should implement learning centered on learners.

\section{References}

Abdurrahman, H. N. (2016). Character education in islamic boarding schoolbased SMA amanah. Jurnal Pendidikan Islam, 2, 287-305.

Althof, W. \& Berkowitz, W.M. (2006). Moral education and character education: their relationship and roles in citizenship education. Journal of Moral Education, 35, 495-518.

Alticulac, A. \& Sabanci, O. (2017). Nationalism perceptions of pre-service social studies teachers in turkey. Journal of Education and Practice, 8, 237-256.

Amran, A. (2016). Pendidikan Pancasila perguruan tinggi. Jakarta: Raja Grafindo Persada.

Anderson, B. R. (1999). Indonesian nationalism today and in the future. Indonesia. New York: Southeast Asia Program Publications at Cornell University.

Anderson, B. R., (2006). Imagined comunities reflection on the origin spread of nationalism, New York: Verso.

Aubakirova, S.S., Ismagambetova, N. Z., \& Karabayeva, G. A. (2016). Tolerance issue in Kazakh culture. International journal of environmental $\mathcal{E}$ science education. 11, 5034-5048

Bahruddin \& Syukron. (2011). Terorism issue and alumny of Islamic boarding school. Humaniora, 8, 33-4.

Balint, P. (2014). Acts of tolerance: A political and descriptive account. European Journal of Political Theory, 13, (3), 264-28.

Beng, H. S., \& James, A. (2011). The potential role of schools and teachers in the character development of young people in England: perspectives from pupils and teachers. Evaluation EO Research in Education, 24, 143-157.

Bennett, W. J. (2001). The broken hearth. New York: Doubleday

Benninga, S. J., Berkowitz, W. M., Kuehn, P., \& Smith, K. (2003). The relationship of character education implementation and academic achievement in 
elementary schools. Journal of Research in Character Education, 1, 19-32.

Bergen, V. W. C., \& Collier, G. (2003). Tolerance as civility in contemporary workplace diversity initiatives. Administrative Issues Journal: Education, Practice, And Research. 3, 86-97.

Borgida, M., Cuffaro, M., \& Muldoon. R. (2011). The conditions of tolerance. Politics, Philosophy Eु Economics, 11, 322-344.

Budimansyah, D. (2010). Tantangan globalisasi terhadap pembinaan wawasan kebangsaan dan cinta tanah air di sekolah. Jurnal Penelitian Pendidikan, 11, 8-16.

Carr, D. (2016). Virtue and Character in Higher Education. British Journal of Educational Studies, 1-16.

Cholisin. (2011). Pengembangan karakter dalam materi pembelajaran PKn. Disampaikan pada kegiatan MGMP PKn SMP Kota Yogyakarta, 18 Januari 2011

Cogan, J., \& Derricot, R. (1999). Citizenship for the 1st century international persepctive on education. London: Cogan Page.

Creswell, W. J. (2015). Penelitian kualitatif dan desain riset, Yogyakarta: Pustaka Pelajar.

Daulay, H.P. (2004). Pendidikan Islam dalam sistem pendidikan nasional di Indonesia. Jakarta: Kencana.

Djupe, A. P., \& Calfano, C. B. (2012). Religious Value Priming, Threat, and Political Tolerance. Political Research Quarterly, 66, (4), 768 -780

Dumford, D. A., Cogswll, A. C., \& Miller, L. A. (2016), The who, what, and where of learning strategies. The Journal of Effective Teaching, 16, 72-88.

Emzir. (2013). Metodelogi penelitian kualitatif analisis data. Jakarta: PT Raja Grafindo Persada

Farisi, I. M. (2014). Bhinneka tunggal ika (unity in diversity), from dynastic polic to classroom practice. Journal of Social Science Education, 13, 46-61.

Hamidi, J. (2010). Civic education antara realita politik dan implementasi hukumnya. Jakarta: Gramedia Pustaka Utama.

Hamruni. (2012). Strategi pembelajaran. Yogyakarta: Insan Madani.

Hermanto, B. (2009). Terorisme dan akar fundamentalisme pesantren (Studi kasus pesantren di Riau dan multikulturalisme agama). Toleransi, 1(2), 276-293. 
Hutchison, L. M. (2014). Tolerating threat? The independent effects of civil conflict on domestic political tolerance. Journal of Conflict Resolution, 58, (5), 796-824

Istiningsih. (2016). Character education of the most depeloved countries in ASEAN. Jornal of Education and e Learning, 3, 32-37,

Janmaat, G. J., \& Mons, N. (2011). Promoting ethnic tolerance and patriotism: The role of education system characteristics. Comparative Education Review, 55, 56-81.

Kaelan. (2010). Pendidikan Pancasila, Yogyakarta: Paradigma.

Kemendikbud. (2016). Konsep dan pedoman pendidikan karakter tingkat sekolah dasar dan menengah pertama, Jakarta : Kemendikbud.

Kemendikbud. (2017). Model silabus mata pelajaran sekolah menengah pertama/ madrasah tsanawiyah (SMP/MTs), Jakarta: Kemendikbud.

Kemenristekdikti. (2016). Buku ajar mat kuliah wajib umum pendidikan kewarganegaraan. Jakarta: Kemenristekdikti.

Majid, A. (2013). Strategi pembelajaran, Bandung: Remaja Rosdakarya.

Milles, M. B., \& Huberman, A. M. (1992). Analisis data kualitatif. (Terjemahan Tjetjep Rohidi \& Mulyarto). Jakarta: UI Percetakan.

Moesa, M. (2007). Nasionalisme kiai konstruksi sosial berbasis agama. Yogyakarta: LKiS.

Verkuyten, M., \& Slooter, L. (2007). Tolerance of Muslim beliefs and practices: Age related differences and context effects. International Journal of Behavioral Development , 31 (5), 467-477 